\title{
ERRATA
}

\section{The Par3-like polarity protein Par3L is essential for mammary stem cell maintenance}

\section{Yongliang Huo and Ian G. Macara}

Nat. Cell Biol. 16, 526-534 (2014); published online 25 May 2014; corrected after print 30 May 2014

In the version of this Article originally published, the scale bars in Fig. $2 c$ should have been labelled ' 3 mm'. In addition, a small red arrow indicating the location of the mutation was missing from Fig. $5 \mathrm{c}$ (shown below). These errors have now been corrected in the online versions of the Article.

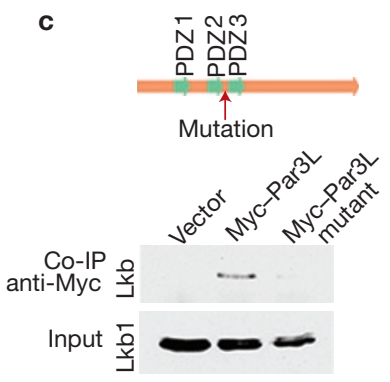

\section{Lipidation of the LC3/GABARAP family of autophagy proteins relies on a membrane-curvature-sensing domain in Atg3}

Sangeeta Nath, Julia Dancourt, Vladimir Shteyn, Gabriella Puente, Wendy M. Fong, Shanta Nag, Joerg Bewersdorf, Ai Yamamoto, Bruno Antonny and Thomas J. Melia

Nat. Cell Biol. 16, 415-424 (2014); published online 20 April 2014; corrected after print 6 June 2014

In the version of this Article originally published, the $x$ axis labels 'WT' and 'K11L' on the graph in Fig. 5c were swapped. This error has now been corrected in all online versions of the Article. 